\title{
ISOLASI DAN IDENTIFIKASI PATOGEN GETAH KUNING MANGGIS MELALUI PENDEKATAN POSTULAT KOCH DAN ANALISIS SECARA MOLEKULER
}

\author{
I Ketut Suada \& Ni Wayan Suniti \\ Program Studi Agroekoteknologi Fakultas Pertanian Universitas Udayana \\ J1. PB. Sudirman Denpasar 80232 \\ E-mail: ketutsuada@yahoo.com
}

\begin{abstract}
Isolation and identification of mangosteen yellow latex pathogen through Koch's Postulate application and molecular analysis. The yellow latex disease decreases fruit quality of mangosteen because exogenic latex causes dirty fruit and the endogenic latex makes the bitter fruit taste and does not deserve to be consumed. The causal agent of the disease caused phusilogical disorder so that cells break due to unstability of cell turgor, the drift irrigation treatment was able to decrease the disease of $35.22 \%$, therefore the causal agent could be microbe that promote the yellow latex. This research was aimed to find the yellow latex pathogens with its characteristics. The Koch Postulate was apllied to isolate and proved the microbes associated to the yellow latex and molecular analysis was constructed subsequently to find the microbe species. The result of the research proved that there were three fungus species as the biotic agent responsible to the disease. The fungus were Verticillium albo-atrum with the highest pathogenecity ( $74.87 \%$ ), followed by Fusarium oxysporum ( $70.15 \%)$, and Pestalotia macrotricha $(20.32 \%)$.
\end{abstract}

Key words: biotic factor, Postulate Koch, yellow latex

\section{ABSTRAK}

Isolasi dan identifikasi patogen getah kuning manggis melalui pendekatan Postulat Koch dan analisis secara molekuler. Getah kuning pada manggis sangat menurunkan kualitas buah karena getah eksogenik menyebabkan buah terlihat kotor dan getah endogenik mengakibatkan rasa buah pahit sehingga tidak layak dikonsumsi. Dugaan penyebab getah kuning adalah abiotik-fisiologis yaitu sel pecah akibat ketidakstabilan air sel, namun perlakuan irigasi tetes hanya menurunkan getah kuning sebesar 35,22\% sehingga patut diduga adanya faktor biotik yang memacu munculnya getah tersebut. Tujuan penelitian adalah menemukan patogen penyebab getah kuning dengan karakteristiknya. Cara penentuannya adalah dengan pendekatan Postulat Koch yaitu isolasi, inokulasi, dan reisolasi yang dilanjutkan dengan analisis molekuler untuk menentukan spesies jamur. Hasil penelitian menunjukkan penyebab getah kuning adalah tiga jenis jamur yaitu Verticillium albo-atrum dengan patogenesitas tertinggi yaitu 74,87\%, diikuti oleh Fusarium oxysporum sebesar 70,15\%, dan Pestalotia macrotricha sebesar $20,32 \%$.

Kata kunci: faktor biotik, getah kuning, Postulat Koch

\section{PENDAHULUAN}

Gangguan penyakit getah kuning (gummosis) merupakan salah satu penyebab utama rendahnya kualitas buah manggis dan hal ini merupakan masalah yang sangat serius yang dihadapi oleh para pelaku agribisnis manggis (Rai et al., 2009). Getah kuning adalah cairan atau eksudat yang keluar dari pembuluh getah kulit buah manggis, seringkali mengotori buah dan menurunkan kualitas buah (Verheij, 1992). Penyakit getah kuning dapat menyebabkan daging buah terlumuri getah kuning, penampilan buah tidak menarik, dan kulit buah menjadi keras sehingga sukar dibelah. Buah yang bergetah kuning rasanya tidak enak dan pahit bahkan tidak layak dimakan, sehingga sangat tidak layak diekspor. Menurut Poerwanto (2000) hanya sekitar 20\% dari total produksi buah manggis layak ekspor karena rendahnya kualitas. Para pelaku agribisnis manggis mulai dari pekebun, pedagang, dan eksportir sangat berharap agar masalah penyakit getah kuning dapat diatasi.

Dugaan sementara, getah kuning diakibatkan oleh penyakit fisiologis yaitu turgor sel jaringan buah berubah secara ekstrim akibat kandungan air sel berubah sehingga sel pecah dan mengeluarkan getah kuning. 
Oleh karena itu untuk menanggulanginya dilakukan upaya irigasi tetes. Penelitian Syah et al. (2007) melalui pengairan yang terus-menerus (metode tetes) yang dilakukan di Kabupaten Lima Puluh Kota dan Pesisir Selatan Sumatera Barat hanya mampu menurunkan kejadian getah kuning sebesar 23\%. Sementara itu, penelitian Rai et al. (2009) menggunakan irigasi tetes dengan penambahan pupuk kalsium dan antitranspiran hanya mampu menurunkan getah kuning sebesar $47,43 \%$. Berdasarkan kedua data tersebut berarti upaya pengendalian belum dapat menuntaskan kejadian penyakit getah kuning manggis. Hal itu sekaligus menunjukkan penyebab getah kuning bukanlah bersifat fisiologis, namun bersifat biologis yaitu adanya gangguan mikroba patogen. Pengamatan yang dilakukan Rai et al. (2009) telah dijumpai mikroba yang berasosiasi dalam getah kuning yaitu Penicillium sp., Fusarium oxysporum, dan Xanthomonas namun belum dibuktikan sebagai patogen penyebab getah kuning. Oleh karena itu perlu dilakukan penelitian yang dapat membuktikan patogen getah kuning dengan menerapkan isolasi, inokulasi, reisolasi, dan identifikasi mikroba yang berasosiasi dan teknik pembuktian ini dikenal dengan metode Postulat Koch. Setelah diketahui mikroba sebagai penyebab maka kemudian mikroba tersebut diidentifikasi secara molekuler. Tujuan penelitian ini adalah untuk menentukan patogen penyebab gejala getah kuning pada buah manggis. Manfaat penelitian ini adalah dengan diketahui patogen penyebab penyakit getah kuning ini maka penyakit ini dapat dikendalikan secara tepat sehingga kualitas buah dapat ditingkatkan.

\section{METODE PENELITIAN}

Tempat dan Waktu. Analisis sampel dilakukan di Laboratorium Bioteknologi Fakultas Pertanian Universitas Udayana, dan analisis molekuler di Laboratory of Forest Research Station, Field Science Center for Nothern Biosphere Hokkaido University. Penelitian ini dilakukan mulai Januari sampai Juli 2013. Bahan yang digunakan adalah buah manggis yang diambil dari pohonnya di sentra produksi manggis Banjar Duren Taluh, Desa Belimbing Kecamatan Pupuan, Tabanan, Bali. Untuk isolasi jamur diperlukan media PDA (Potato Dextrose Agar) yang mengandung 0,1\% kloramfenikol dan media CPGA (Casamino Potato Glucose Agar) mengandung $0,1 \%$ PCNB (Pentachloro Nitro Benzena) untuk mengisolasi bakteri. Alat yang digunakan berupa mesin PCR (Thermal cycler), alat DNA elektroforesis, cawan Petri, kulkas $-4^{\circ} \mathrm{C}$, enkast untuk ruang isolasi, pewarna jaringan xillol, dan kapas steril.
Pengamatan Intensitas Penyakit. Buah yang bergetah kuning, diamati/diambil sebanyak 3 (tiga) kali yaitu pada umur 5 Minggu Setelah Bunga Mekar (MSBM), 10 MSBM, dan 15 MSBM. Masa pengamatan ini merupakan masa perkembangan dan kematangan buah menurut kriteria Rai (2007). Pengamatan buah yang terserang getah kuning dibedakan menjadi persentase buah yang bergetah kuning di kulit buah bagian luar dan persentase buah yang bergetah kuning di kulit buah bagian dalam. Setiap pengamatan, 10 buah manggis per pohon dipetik secara acak untuk diamati di laboratorium. Intensitas getah kuning di kulit buah bagian luar dihitung menggunakan rumus:

$$
I=\frac{\sum(n \times v)}{N \times Z} \times 100 \%
$$

$\mathrm{I}=$ intensitas serangan

$\mathrm{n}=$ jumlah buah yang terserang dengan nilai skor tertentu

$\mathrm{v}=$ harga numerik tiap tingkat kerusakan (skor)

$\mathrm{N}=$ jumlah semua sampel yang diamati

$\mathrm{Z}=$ nilai tingkat kerusakan (skor) tertinggi

Skor tingkat kerusakan yang digunakan mengikuti kriteria Rai et al. (2009) yaitu :

$1=$ baik sekali, kulit mulus tanpa tetesan getah kuning

$2=$ kulit mulus, dengan 1-5 tetes getah kunuing tanpa mempengaruhi warna buah

3 = cukup baik, kulit mulus dengan 6-10 tetes getah uning tanpa mempengaruhi warna buah

$4=$ buruk, kulit kotor karena getah kuning dan ada bekas aliran membentuk jalur-jalur berwarna kuning di permukaan buah

$5=$ buruk sekali, kulit kotor karena tetesan getah kuning dan terdapat bekas aliran membentuk jalur-jalur berwarna kuning di permukaan buah, buah menjadi kusam dan keras

Persentase buah yang daging buah/arilnya terkena getah kuning dihitung dengan rumus:

$$
\mathrm{P}=\frac{\mathrm{A}}{\mathrm{B}} \times 100 \%
$$

$\mathrm{P}=$ persentase serangan

$\mathrm{A}=$ jumlah contoh buah yang daging buah/arilnya ditemukan adanya noda getah kuning

$\mathrm{B}=$ jumlah contoh buah yang diamati

Pengambilan Sampel Buah Manggis Bergetah Kuning dan Isolasi Patogen. Buah contoh diambil dari pohon yang menunjukkan gejala getah kuning sebanyak 10 buah manggis dan diamati di laboratorium. 
Setelah diseka dengan alkohol 70\% sebanyak tiga kali, bagian jaringan di sekitar getah $\left( \pm 2 \mathrm{~mm}^{2}\right)$ dan getahnya sendiri diambil secara aseptik kemudian direndam dalam natrium hipoklorit $2 \%$ selama 5 menit, lalu dibilas dengan akuades sebanyak tiga kali dan dikeringkan dengan kertas tissue steril. Bagian jaringan tersebut kemudian diinkubasi selama lima hari pada media PDAkloramfenikol untuk mendapatkan isolat jamur dan media CPGA-PCNB untuk isolat bakteri. Jamur dan atau bakteri yang tumbuh disubkultur pada media baru masing-masing sampai didapatkan biakan murni.

Inokulasi Isolat Patogen. Setelah didapatkan biakan murni, tiap isolat diinokulasikan satu persatu pada buah manggis sehat baik di laboratorium maupun di pohon menggunakan kapas steril yang sebelumnya telah disentuhkan/dicolekkan pada biakan mikroba. Tiap isolat diinokulasikan dengan ulangan 10 sampai 19 kali (buah manggis) dan diletakkan dalam kotak plastik ukuran $20 \times 30 \times 10 \mathrm{~cm}^{2}$ (percobaan di laboratorium). Inokulasi ini dilakukan pada buah umur 5 MSBM, 10 MSBM, dan 15 MSBM baik di laboratorium maupun di pohon. Sebelum inokulasi, permukaan buah diseka tiga kali dengan alkohol $70 \%$. Gejala getah kuning yang muncul pada buah manggis di laboratorium dan di pohon diamati kemudian ditentukan skornya.

Reisolasi Isolat Patogen. Buah yang diperlakukan di pohon dipetik kemudian dibawa ke laboratorium untuk diisolasi langsung mikrobanya. Buah yang bergejala (di laboratorium dan dari pohon) diseka dengan alkohol $70 \%$ kemudian dibelah dan bagian jaringan di sekitar batas gejala $\left( \pm 2 \mathrm{~mm}^{2}\right)$ diambil dan direndam dalam natrium hipoklorit $2 \%$ selama 5 menit, dibilas akuades tiga kali lalu dikeringkan dengan tissu steril. Sebagian potongan jaringan tersebut dikultur pada media PDAkloramfenikol untuk menumbuhkan jamur dan sebagian lagi pada media CPGA-PCNB untuk menumbuhkan bakteri. Mikroba yang tumbuh dalam masing-masing media tersebut disubkultur beberapa kali sampai didapat biakan murni yang siap diidentifikasi. Selanjutnya, bagian jaringan yang bergejala getah kuning maupun tidak, diamati di bawah mikroskop untuk mengetahui perbedaan struktur antara kedua jaringan tersebut.

Identifikasi Isolat Patogen. Isolat patogen hasil reisolasi yang menimbulkan gejala getah kuning diidentifikasi secara visual di bawah mikroskop dengan mencocokkan ciri-ciri jamur yang teramati terhadap pustaka yang ada (Barnett \& Hunter, 1998; CMI, 1981), sedangkan analisis secara molekulernya dilakukan dengan cara sebagai berikut. DNA miselium jamur isolat tersebut diekstrak menggunakan NucleoSpin Plant II MACHEREY-NAGEL GmbH \& Co. KG (Germany). Amplifikasi DNA daerah ITS (Internal Transcribed Spacer region in the nuclear ribosomal repeat unit) yang mencakup 5,8S-rDNA dilakukan menggunakan Thermal Cycler (Infinigen Biotech Inc., USA) menggunakan 2x PCR Master Mix Solution (i-Taq) iNtRON Biotechnology (Germany) dengan primer spesifik (SIGMA) yaitu ITS 1: (5'TCCGTAGGT GAACCTTGCGG3') (Gardes \& Bruns, 1993) dan satu primer universal ITS4: (5'TCCTCCGCTTATTG ATATGC3') (White et al., 1990). Kondisi PCR terdiri dari: persiapan (initialization) $94^{\circ} \mathrm{C} 10$ menit, diikuti denaturasi (denaturation) pada $94^{\circ} \mathrm{C}$ selama 1 menit, penempelan primer (annealing) pada suhu $55^{\circ} \mathrm{C}$ selama 1,5 menit sebanyak 30 siklus, dan pemanjangan (elongation) $72^{\circ} \mathrm{C}$ selama 2 menit, serta proses final dipertahankan pada suhu $72^{\circ} \mathrm{C}$ selama 5 menit. Kualitas dan kuantitas produk PCR ditentukan dengan elektroforesis gel agarose-LE Classic type NACALAI TESQUE Inc., Kyoto Japan menggunakan CBS Scientific Co. Inc. Masing-masing produk PCR dimurnikan menggunakan NucleoSpin Gel and PCR Clean-up purification kit (MACHEREY-NAGEL Germany) dan kemudian disekuens dengan primer ITS1 dan ITS4 yang dilakukan di Forest Research Station, Field Science Center for Nothern Biosphere, Hokkaido University, Japan. Reaksi sekuens mengikuti prosedur Solgent Co., Ltd. (Daejeon, Korea). Sekuens DNA yang diperoleh dibandingkan dengan data base GenBank di National Center for Biotechnology Information (NCBI) menggunakan Nucleotide basic alignment search tool algorithm (BLAST program). Sekuens tersebut dicocokkan dengan sekuens yang paling dekat kemudian dilakukan analisis neighborjoining (NJ) di NCBI untuk menginterpretasikan tingkat spesies, genus, dan famili. Sekuens dianggap teridentifikasi tingkat spesies jika lebih dari $97 \%$ sesuai dengan sekuens referensi yang diperoleh dari sporokarp spesies yang sama dan sekaligus membentuk pohon tunggal dengan spesimen pohon NJ. Jika kecocokan tersebut kurang dari $97 \%$ maka identitas jamur tersebut adalah pada tingkat genus atau famili sesuai dengan diagram filogenetik yang diperoleh.

\section{HASIL DAN PEMBAHASAN}

Persentase Getah Kuning. Getah kuning yang mengotori/keluar ke permukaan luar buah disebut Getah Kuning Eksogenik dan yang ke dalam mengotori aril buah disebut Getah Kuning Endogenik. Persentase serangan getah kuning eksogenik pada buah cukup tinggi 
seperti ditunjukkan pada Tabel 1. Persentase getah kuning rata-rata dari 10 pohon tanaman manggis (35 buah per pohon) adalah $36,93 \pm 17 \%$. Getah kuning terbanyak terjadi pada masa $10 \mathrm{MSBM}$ yaitu sebesar $41,20 \pm 9 \%$. Tingginya persentase getah kuning pada 10 MSBM ini kemungkinan disebabkan karena aktivitas biologis buah mengalami puncaknya sehingga getah kuning sebagai metabolit sekunder normal pada manggis terbentuk maksimum. Getah kuning yang terbentuk dalam buah manggis adalah akibat terbentuknya metabolit sekunder sebagai proses metabolisme normal tumbuhan seperti pada Famili Rubiaceae. Getah tersebut akan mengalir dan tertampung pada saluran latisifer (saluran getah buah, Gambar 1) sebagai proses yang normal dan dapat juga dipacu akibat adanya gangguan jamur. Latisifer adalah sel sekresi yang memanjang yang ditemukan dalam daun/batang/buah tanaman yang memproduksi lateks/karet sebagai metabolit sekunder. Ada 2 jenis latisifer yaitu: 1) latisifer artikulasi yaitu serial sel lateks yang bergabung, contoh xilem; 2) nonartikulasi yaitu satu sel memanjang (syncytial cell) yang pertama kali dijelaskan oleh de Barry pada tahun 1887. Fungsi getah latisifer adalah penyembuhan luka, pertahanan terhadap herbivora, dan untuk keperluan taksonomi (Famili Euphorbiaceae). Contoh tanaman famili ini adalah karet, kamboja, alamanda, jarak, dan Plumeria obtusa (Mahlberg, 1993).

Keluarnya getah kuning baik yang bersifat eksogenik maupun endogenik pada manggis adalah karena adanya penumpukan getah pada latisifer tersebut yang jika kondisinya penuh maka tekanannya meningkat dan akhirnya mencari jalan ke luar lewat latisifer yang bermuara pada lapisan luar maupun dalam buah.

Tabel 1. Persentase getah kuning eksogenik (permukaan luar buah) dan getah kuning endogenik (pada aril buah) berdasarkan umur buah

\begin{tabular}{ccccc}
\hline \multicolumn{2}{c}{ Getah kuning eksogenik $(\mathrm{X} \pm \mathrm{SE} \%)$} & & Getah kuning endogenik $(\mathrm{X} \pm \mathrm{SE} \%)$ \\
5 MSBM & $10 \mathrm{MSBM}$ & $15 \mathrm{MSBM}$ & & 15 MSBM \\
\hline $35,00 \pm 10$ & $41,20 \pm 9$ & $34,60 \pm 14$ & & $72,00 \pm 25$ \\
\hline $\begin{array}{l}\text { Rata-rata getah kuning eksogenik } \\
\text { pada manggis selama penelitian }\end{array}$ & $36,93 \pm 17$ & & \\
\hline
\end{tabular}

Keterangan: MSBM=minggu setelah bunga mekar, $\mathrm{SE}=$ Standard Error pengukuran.

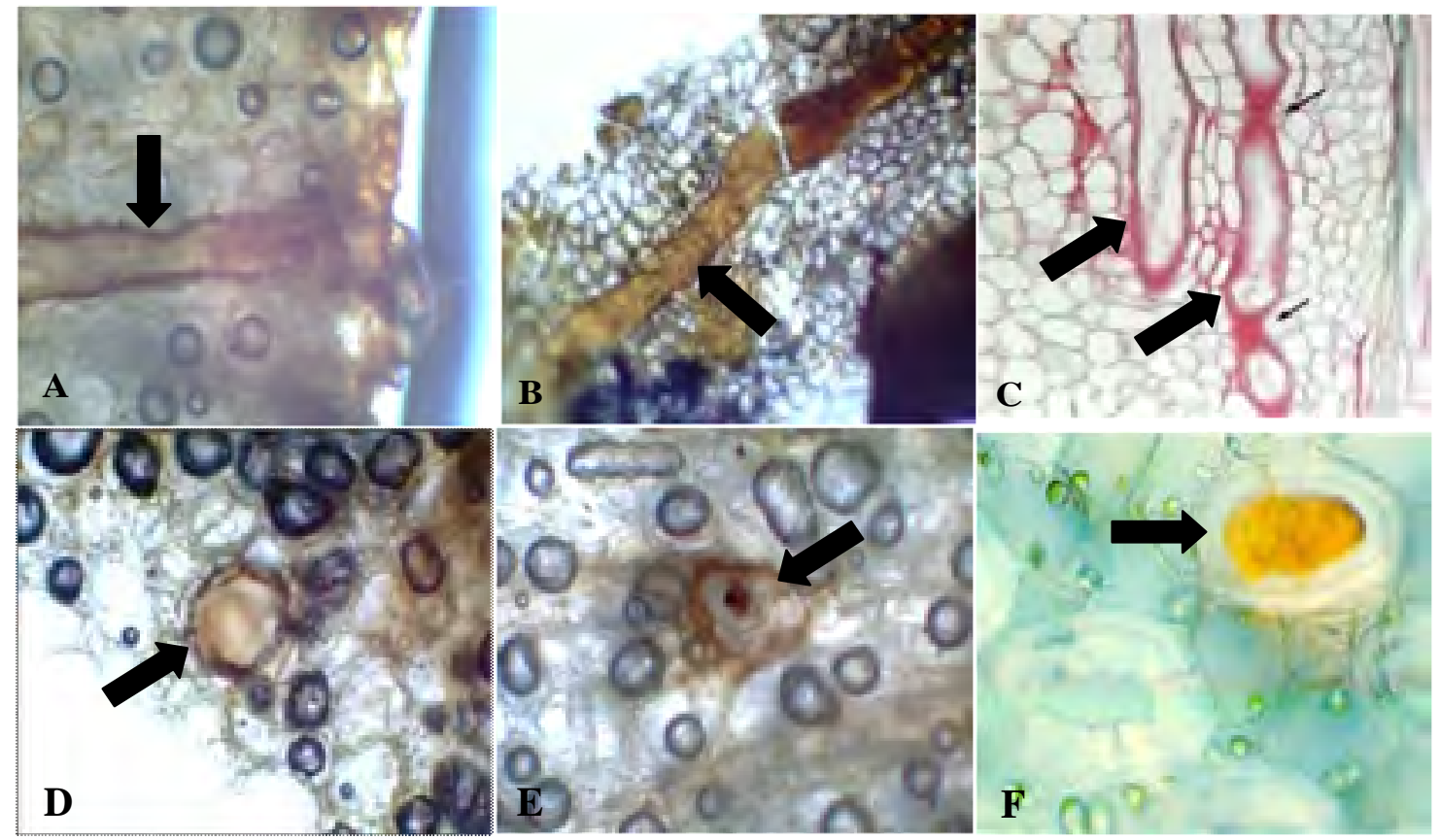

Gambar 1. Saluran latisifer tempat penampungan getah kuning dalam jaringan buah (200X). (A-C) gambar memanjang, (D-F) gambar melintang, (F) latisifer mengandung getah; (A,B,D,E) Saluran latisifer hasil penelitian; (C,F) saluran latisifer sebagai pembanding. (Sumber: http://images.search.yahoo.com/ images/view;ylt=A0PDoX.vgv1RflkA0j2jzbkF, diakses pada 10 Agustus 2013). 
Disamping sel latisifer memang terbentuk normal pada perkembangan buah, saluran getah juga akan terbentuk sembarang pada sel-sel buah yang lemah dan menjadi terusan dari saluran latisifer yang mengantarkan getah ke permukaan buah (Dorly et al., 2008). Peranan mikroba terutama miselium jamur selanjutnya adalah membantu mengalirkan getah dari sel-sel sekitar saluran ke latisifer. Jamur yang tumbuh akan melubangi sel dan langsung mengalirkan getah kuning ke saluran latisifer sehingga tekanan getah pada saluran tersebut meningkat dan akhirnya keluar baik sebagai getah kuning eksogenik maupun endogenik. Jika saluran latisifer alami maupun terusannya bermuara dekat dengan permukaan dan menembusnya ke luar disebut sebagai getah Kuning Eksogenik dan jika tembus ke dalam dan mengenai aril disebut Getah Kuning Endogenik.

\section{Mikroba Penyebab/Pemacu Getah Kuning.} Mikroba penyebab getah kuning adalah jamur yaitu mikroba yang berbentuk benang dan memiliki tubuh buah yang berbeda-beda antar jenis sebagai ciri khas genus maupun spesies. Jamur tumbuh dalam jaringan tanaman dan mendapatkan makanan dari sel tanaman manggis sebagai inangnya. Jamur yang ditemukan pada getah kuning sebagai hasil isolasi dari getah dan jaringan di sekitar keluarnya getah baik eksogenik maupun endogenik adalah sebanyak 14 jenis jamur dan dua jenis bakteri. Setelah jamur dan bakteri tersebut diinokulasikan mengikuti Postulat Koch, baik pada buah di laboratorium maupun pada buah di pohon, hanya 3 jenis jamur yang mampu menghasilkan gejala getah kuning sedangkan yang lain termasuk bakteri tidak dapat menimbulkan gejala getah kuning (Gambar 2).

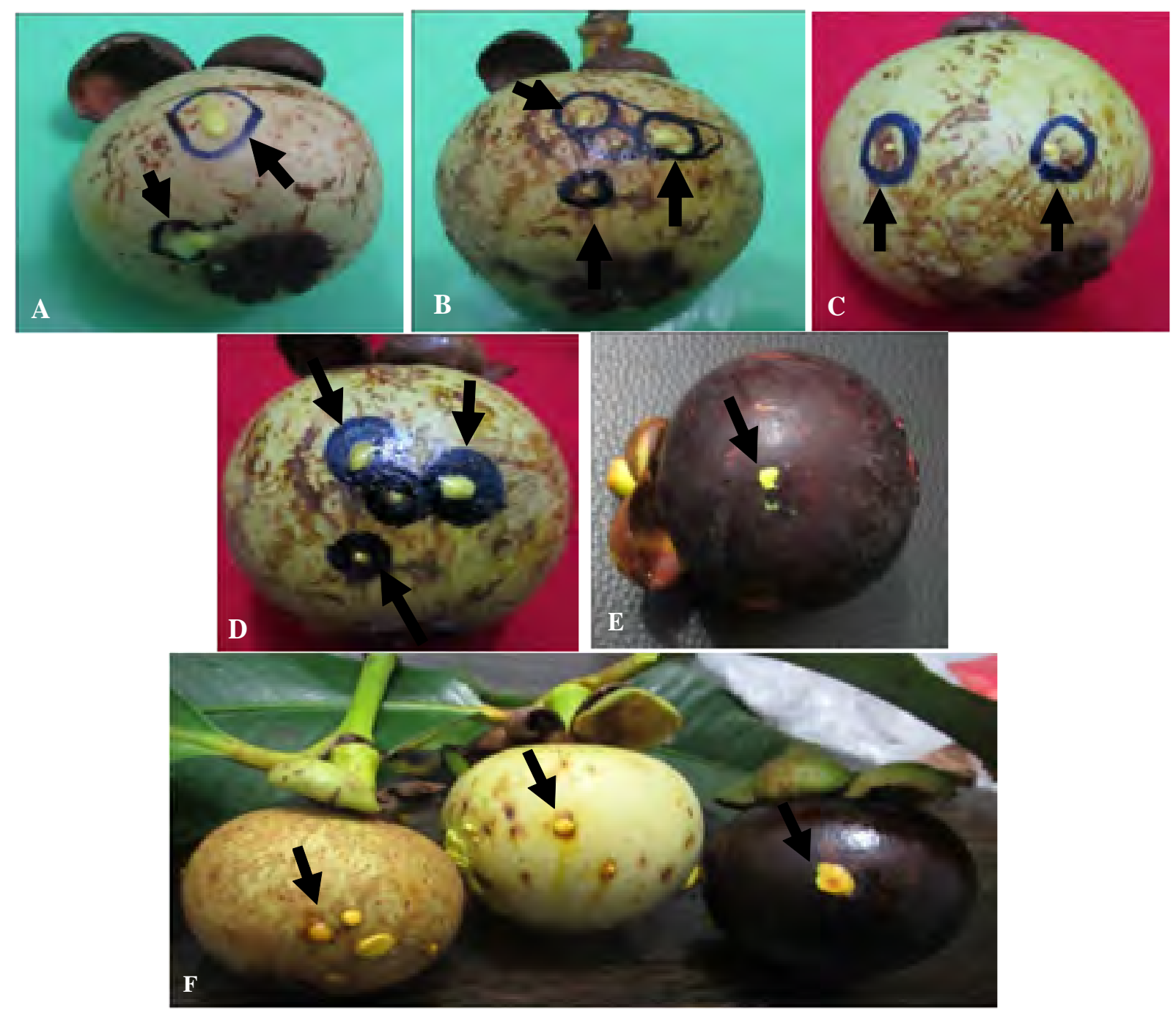

Gambar 2. (A,B,C,D,E) Gejala getah kuning yang muncul setelah diinokulasi dengan isolat jamur pemacu getah kuning pada buah di laboratorium dan (F) buah di pohon, (A-C) gejala getah kuning pada buah umur 5 MSBM, D=10 MSBM, dan E=15 MSBM 
Tiga jenis jamur yang diuji melalui Postulat Koch (Gambar 3) tersebut mampu menimbulkan gejala getah kuning yang bersifat eksogenik dengan tingkat patogenisitas yang berbeda. Setelah dilakukan identifikasi secara visual di bawah mikroskop dan dilanjutkan dengan analisis molekuler maka didapat nama spesies jamur tersebut. Jamur tersebut adalah Verticillium albo-atrum, Fusarium oxysporum, dan Pestalotia macrotricha (Tabel 2). Jamur V. alboatrum mampu menimbulkan gejala getah kuning pada hari ke-5 setelah inokulasi dengan jumlah titik getah 1-5 buah gejala dengan skor 1-2 dan intensitas serangan pada buah tertinggi yaitu $74,87 \%$, diikuti oleh
F. oxysporum sebesar $70,15 \%$ dan P. macrotricha dengan intensitas serangan 20,32\%.

Masing-masing DNA isolat jamur seperti pada Gambar 3 diisolasi, kemudian di PCR, dan hasilnya disekuens menggunakan sistem BLAST untuk mengidentifikasi jenis jamur. Identifikasi jamur patogen getah kuning dilakukan dengan cara analisis DNA menggunakan Phytoplan Kit II kemudian DNA spesifiknya diperbanyak dengan rPrimer dan fPrimer pada thermal cycler machine PCR kemudian disekuens dan dicocokkan dengan sistem $B L A S T$ sehingga diperoleh nama spesies jamur dengan kecocokan tertinggi seperti pada Tabel 3.

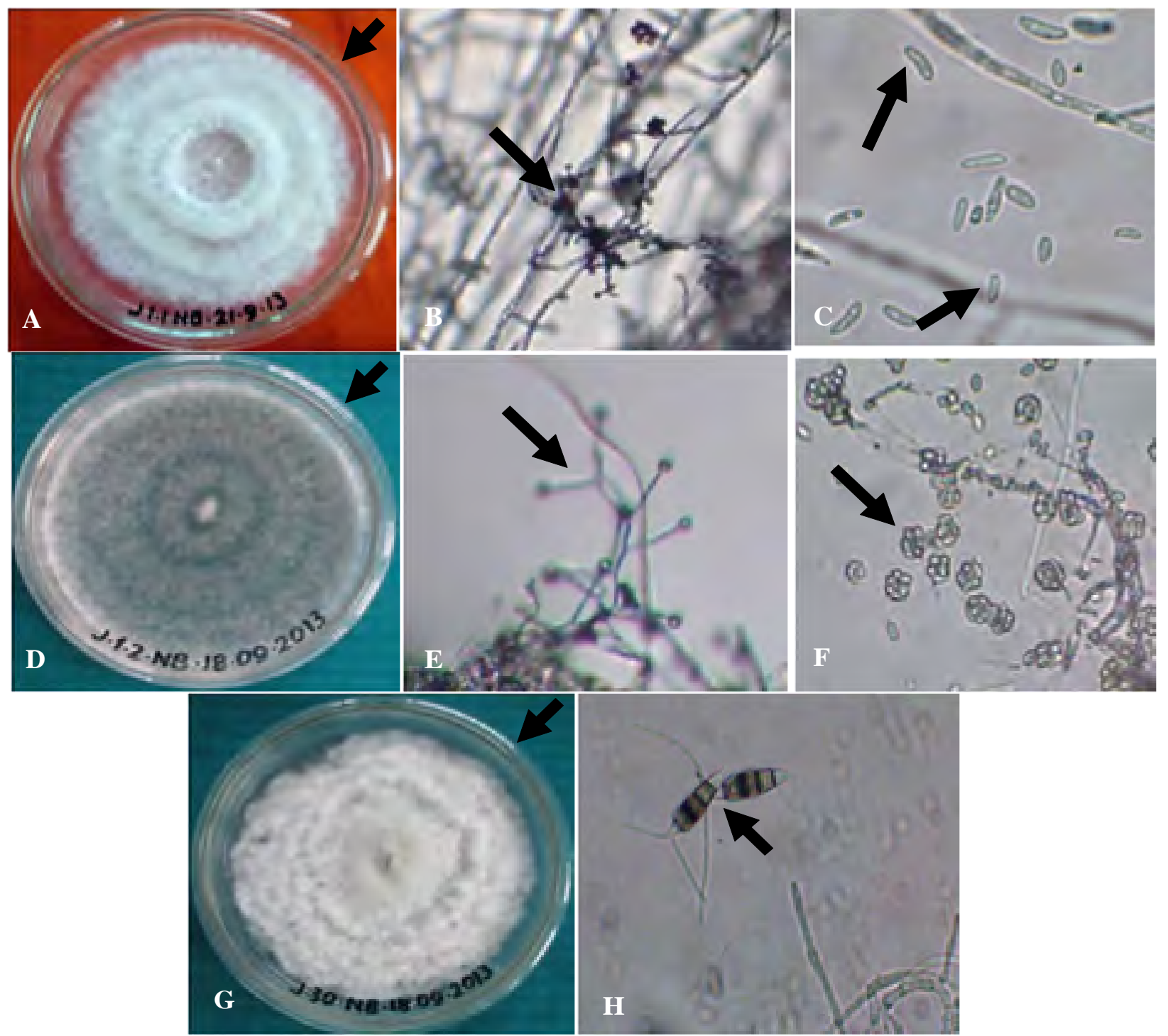

Gambar 3. Morfologi jamur pemacu getah kuning pada media PDA. (A) koloni, (B) miselium dengan tubuh buah, (C) spora Fusarium oxysporum; (D) koloni, (E) tubuh buah, (F) spora Verticillium albo-atrum; (G) koloni, (H) spora Pestalotia macrotricha. 


\begin{tabular}{|c|c|c|c|c|c|c|}
\hline $\begin{array}{l}\text { Nomor } \\
\text { isolat }\end{array}$ & $\begin{array}{l}\text { Jenis } \\
\text { mikroba }\end{array}$ & $\begin{array}{l}\text { Hasil inokulasi } \\
\text { pada buah di } \\
\text { lab. }\end{array}$ & $\begin{array}{l}\text { Kemunculan getah } \\
\text { kuning hasil } \\
\text { inokulasi pada buah }\end{array}$ & $\begin{array}{l}\text { Kemunculan getah kuning hasil } \\
\text { inokulasi pada buah di pohon } \\
\text { (pada } 10 \text { hari setelah inokulasi) }\end{array}$ & $\begin{array}{l}\text { Rataan kemunculan } \\
\text { getah kuning pada buah } \\
\text { (di lab dan pohon) }\end{array}$ & $\begin{array}{l}\text { Karakteristik } \\
\text { pertumbuhan koloni di } \\
\text { media PDA di lab. }\end{array}$ \\
\hline $\begin{array}{l}1 \\
(\mathrm{~J} 1.1)\end{array}$ & $\begin{array}{l}\text { Jamur: } \\
\text { Pestalotia } \\
\text { macrotricha } \\
\text { de NOT }\end{array}$ & $\begin{array}{l}\text { Menimbulkan } \\
\text { gejala pada } 11 \\
\text { hsi }\end{array}$ & $\begin{array}{l}\text { Jumlah getah kuning } \\
0-3 \text { titik (skor 1-2) } \\
\text { Kemunculan gejala } \\
23,5 \% \text { (sampel } 17 \\
\text { buah) }\end{array}$ & $\begin{array}{l}\text { Jumlah getah kuning 1-5 titik } \\
\text { (skor 1-3) } \\
\text { Kemuncu lan gejala 17,14\% } \\
\text { (sampel } 35 \text { buah) }\end{array}$ & $20,32 \%$ & $\begin{array}{l}\text { Koloni tumbuh cepat: } \\
\text { pada biakan umur } 3 \\
\text { hari mencapai } \\
\text { diameter rata-rata } 3,2 \\
\mathrm{~cm}\end{array}$ \\
\hline${ }^{2}(\mathrm{~J} 1.2)$ & $\begin{array}{l}\text { Jamur: } \\
\text { Verticillium } \\
\text { albo-atrum }\end{array}$ & $\begin{array}{l}\text { Menimbulkan } \\
\text { Gejala pada } 5 \\
\text { hsi }\end{array}$ & $\begin{array}{l}\text { Jumlah getah kuning } \\
1-5 \text { titik (skor 1-2) } \\
\text { Kemunculan gejala } \\
84,21 \% \text { (sampel } 19 \\
\text { buah) }\end{array}$ & $\begin{array}{l}\text { Jumlah getah kuning } 1-5 \text { titik } \\
\text { (skor } 1-2 \text { ) } \\
\text { Kemuncu lan gejala } 65,52 \% \\
\text { (sampel } 29 \text { buah) }\end{array}$ & $74,87 \%$ & $\begin{array}{l}\text { Koloni tumbuh sangat } \\
\text { cepat: pada biakan } \\
\text { umur } 3 \text { hari telah } \\
\text { mencapai diameter } \\
\text { rata-rata } 4,7 \mathrm{~cm}\end{array}$ \\
\hline $\begin{array}{l}3 \\
(\mathrm{~J} 30)\end{array}$ & $\begin{array}{l}\text { Jamur: } \\
\text { Fusarium } \\
\text { oxysporum }\end{array}$ & $\begin{array}{l}\text { Menimbulkan } \\
\text { gejala pada } 7 \text { hsi }\end{array}$ & $\begin{array}{l}\text { Jumlah getah kuning } \\
0-3 \text { titik (skor } 1-2 \text { ) } \\
\text { Kemunculan gejala } \\
76,9 \% \text { (sampel } 13 \\
\text { buah) }\end{array}$ & $\begin{array}{l}\text { Jumlah getah kuning } 0-3 \text { titik } \\
\text { (skor } 1-2 \text { ) } \\
\text { Kemunculan gejala } 63,4 \% \\
\text { (sampel } 30 \text { buah) }\end{array}$ & $70,15 \%$ & $\begin{array}{l}\text { Koloni tumbuh cepat: } \\
\text { pada biakan umur } 3 \\
\text { hari telah mencapai } \\
\text { diameter } 2,6 \\
\mathrm{~cm}\end{array}$ \\
\hline 4 & Jamur & $\begin{array}{l}\text { Tidak } \\
\text { menimbulkan } \\
\text { gejala sampai } 11 \\
\text { hsi }\end{array}$ & - & Tidak menimbulkan gejala & 0 & $\begin{array}{l}\text { Koloni tumbuh cepat: } \\
\text { pada biakan umur } 3 \\
\text { hari telah mencapai } \\
\text { diameter } 3,5 \mathrm{~cm}\end{array}$ \\
\hline 5 & Jamur & $\begin{array}{l}\text { Tidak } \\
\text { menimbulkan } \\
\text { gejala sampai } 11 \\
\text { hsi }\end{array}$ & - & Tidak menimbulkan gejala & 0 & $\begin{array}{l}\text { Koloni tumbuh cepat: } \\
\text { pada biakan umur } 3 \\
\text { hari telah mencapai } \\
\text { diameter } 3,5 \mathrm{~cm}\end{array}$ \\
\hline 6 & Jamur & $\begin{array}{l}\text { Tidak } \\
\text { menimbulkan } \\
\text { gejala sampai } 11 \\
\text { hsi }\end{array}$ & - & Tidak menimbulkan gejala & 0 & $\begin{array}{l}\text { Koloni tumbuh cepat: } \\
\text { pada biakan umur } 3 \\
\text { hari telah mencapai } \\
\text { diameter } 3,5 \mathrm{~cm}\end{array}$ \\
\hline 7 & Jamur & $\begin{array}{l}\text { Tidak } \\
\text { menimbulkan } \\
\text { gejala sampai } 11\end{array}$ & - & Tidak menimbulkan gejala & 0 & $\begin{array}{l}\text { Koloni tumbuh cepat: } \\
\text { pada biakan umur } 3 \\
\text { hari telah mencapai }\end{array}$ \\
\hline
\end{tabular}


Tabel 2. lanjutan

\begin{tabular}{|c|c|c|c|c|c|c|}
\hline $\begin{array}{l}\text { Nomor } \\
\text { isolat }\end{array}$ & $\begin{array}{l}\text { Jenis } \\
\text { mikroba }\end{array}$ & $\begin{array}{l}\text { Hasil inokulasi } \\
\text { pada buah di } \\
\text { lab. }\end{array}$ & $\begin{array}{l}\text { Kemunculan getah } \\
\text { kuning hasil } \\
\text { inokulasi pada buah }\end{array}$ & $\begin{array}{l}\text { Kemunculan getah kuning hasil } \\
\text { inokulasi pada buah di pohon } \\
\text { (pada } 10 \text { hari setelah inokulasi) }\end{array}$ & $\begin{array}{l}\text { Rataan kemunculan } \\
\text { getah kuning pada buah } \\
\text { (di lab dan pohon) }\end{array}$ & $\begin{array}{l}\text { Karakteristik } \\
\text { pertumbuhan koloni di } \\
\text { media PDA di lab. }\end{array}$ \\
\hline 8 & Jamur & $\begin{array}{l}\text { Tidak } \\
\text { menimbulkan } \\
\text { gejala sampai } 11 \\
\text { hsi }\end{array}$ & - & Tidak menimbulkan gejala & 0 & $\begin{array}{l}\text { Koloni tumbuh cepat: } \\
\text { pada biakan umur } 3 \\
\text { hari telah mencapai } \\
\text { diameter } 3,5 \mathrm{~cm}\end{array}$ \\
\hline 9 & Jamur & $\begin{array}{l}\text { Tidak } \\
\text { menimbulkan } \\
\text { gejala sampai } 11 \\
\text { hsi }\end{array}$ & - & Tidak menimbulkan gejala & 0 & $\begin{array}{l}\text { Koloni tumbuh cepat: } \\
\text { pada biakan umur } 3 \\
\text { hari telah mencapai } \\
\text { diameter } 2,5 \mathrm{~cm}\end{array}$ \\
\hline 10 & Jamur & $\begin{array}{l}\text { Tidak } \\
\text { menimbulkan } \\
\text { gejala sampai } \\
\text { pengamatan } 11 \\
\text { hsi }\end{array}$ & - & Tidak menimbulkan gejala & 0 & $\begin{array}{l}\text { Koloni tumbuh cepat: } \\
\text { pada biakan umur } 3 \\
\text { hari telah mencapai } \\
\text { diameter } 3,5 \mathrm{~cm}\end{array}$ \\
\hline 11 & Jamur & $\begin{array}{l}\text { Tidak } \\
\text { menimbulkan } \\
\text { gejala sampai } 11 \\
\text { hsi }\end{array}$ & - & Tidak menimbulkan gejala & 0 & $\begin{array}{l}\text { Koloni tumbuh cepat: } \\
\text { pada biakan umur } 3 \\
\text { hari telah mencapai } \\
\text { diameter } 3,0 \mathrm{~cm}\end{array}$ \\
\hline 12 & Jamur & $\begin{array}{l}\text { Tidak } \\
\text { menimbulkan } \\
\text { gejala sampai } 11 \\
\text { hsi }\end{array}$ & - & Tidak menimbulkan gejala & 0 & $\begin{array}{l}\text { Koloni tumbuh } \\
\text { lambat: pada biakan } \\
\text { umur } 3 \text { hari baru } \\
\text { mencapai diameter } 4 \\
\text { mm }\end{array}$ \\
\hline 13 & Jamur & $\begin{array}{l}\text { Tidak } \\
\text { menimbulkan } \\
\text { gejala sampai } 11 \\
\text { hsi }\end{array}$ & - & Tidak menimbulkan gejala & 0 & $\begin{array}{l}\text { Koloni tumbuh cepat: } \\
\text { pada biakan umur } 3 \\
\text { hari telah mencapai } \\
\text { diameter } 3,5 \mathrm{~cm}\end{array}$ \\
\hline 14 & Jamur & $\begin{array}{l}\text { Tidak } \\
\text { menimbulkan } \\
\text { gejala sampai } 11 \\
\text { hsi }\end{array}$ & - & Tidak menimbulkan gejala & 0 & $\begin{array}{l}\text { Koloni tumbuh cepat: } \\
\text { pada biakan umur } 3 \\
\text { hari telah mencapai }\end{array}$ \\
\hline
\end{tabular}
hsi 
Tabel 3. Identitas molekuler jamur pemacu getah kuning

\begin{tabular}{|c|c|c|c|c|}
\hline \multirow{2}{*}{ No } & \multirow[b]{2}{*}{$\begin{array}{l}\text { Identitas berdasarkan BLAST } \\
\text { dan analisis filogenetik }\end{array}$} & \multicolumn{3}{|c|}{ Kecocokan BLAST dengan kemiripan tertinggi } \\
\hline & & $\begin{array}{l}\text { Penjelasan } \\
\text { (Definition) }\end{array}$ & $\begin{array}{c}\text { No Asesi (Acession } \\
\text { number) }\end{array}$ & $\begin{array}{c}\text { Kesamaan sekuens } \\
\text { (Overlapped sequence) }\end{array}$ \\
\hline 1 & Pestalotia macrotricha & $\begin{array}{l}\text { Pestalotia } \\
\text { macrotricha KYO for } \\
18 \mathrm{~S} \text { rRNA genes }\end{array}$ & AB540581 & $611 / 620(98 \%)$ \\
\hline 2 & Verticillium albo-atrum & $\begin{array}{l}\text { Verticillium albo- } \\
\text { atrum strain HDFE1 } \\
\text { 18S rRNA gene }\end{array}$ & HM486421 & $500 / 502(99 \%)$ \\
\hline 3 & Fusarium oxysporum & $\begin{array}{l}\text { Fusarium oxysporum } \\
\text { strain YS-01 }\end{array}$ & HQ671180 & $521 / 523(99 \%)$ \\
\hline
\end{tabular}

\section{SIMPULAN}

Telah diisolasi sebanyak 14 jenis jamur dan 2 jenis bakteri dari getah kuning manggis. Hanya tiga jenis jamur diantaranya mampu memacu munculnya getah kuning dengan tingkat kemampuan yang berbeda. Berdasarkan morfologi dan analisis molekuler, spesies jamur yang paling kuat patogenisitasnya adalah Verticillium albo-atrum yaitu sebesar $74,87 \%$ diikuti oleh Fusarium oxysporum 70,15\%, dan Pestalotia macrotricha sebesar $20,32 \%$. Getah kuning yang mengalir menuju ke luar buah dan muncul dipermukaan kulit luar buah disebut sebagai Getah Kuning Eksogenik dan yang mengalir ke dalam dan membasahi aril buah disebut Getah Kuning Endogenik. Munculnya getah kuning eksogenik tidak selalu diikuti oleh getah kuning endogenik sebab getah kuning akan mengalir ke luar atau ke dalam buah mengikuti saluran latisifer yang keberadaannya/terbentuknya bersifat acak dalam jaringan buah manggis.

\section{SANWACANA}

Penulis menyampaikan terima kasih sebesarbesarnya kepada Bapak Eka asal Banjar Duren Taluh, Desa Belimbing, Kecamatan Pupuan, Kabupaten Tabanan, Bali atas izin penggunaan tanaman manggis di lahannya sebagai tempat penelitian serta telah secara tulus ikhlas membantu pengamatan lapangan selama penelitian berlangsung. Kepada Rektor melalui Ketua LP2M Universitas Udayana kami sangat berterimakasih atas dana yang diberikan sehingga penelitian ini dapat berjalan dengan baik.

\section{DAFTAR PUSTAKA}

Barnett HL \& BB Hunter. 1998. Illustrated Genera of Imperfect Fungi. 4th Ed. APS Press, Minnesota.

CMI. 1981. Description of Pathogenic Fungi and Bacteria. Commonwealth Mycology Institute, England.

Dorly S, Tjitrosemito, Poerwanto R \& Juliarini. 2008. Secretory duct structure and phytochemistry compounds of yellow latex in mangosteen fruit. Hayati Journal of Bioscience 15(3): 99-104.

Gardes M \& Bruns TD. 1993. ITS primers with enhanced specificity for basidiomycetes: application to the identification of mycorrhizae and rusts. Molecular Ecology 2: 113-118.

Mahlberg PG. 1993. Laticifers-an historical perspective. Botanical Review 59(1): 1-23.

Poerwanto R. 2000. Teknologi Budidaya Manggis. Makalah Disampaikan pada Diskusi Nasional Bisnis dan Teknologi Manggis, Kerjasama Pusat Kajian Buah-buahan Tropika dengan Direktorat Jenderal Hortikultura dan Aneka Tanaman, Departemen Pertanian, Bogor.

Rai IN. 2007. Bunga dan buah gugur pada tanaman manggis (Garcinia mangostana L.) asal biji dan sambungan. Agritrop. 26(2): 66-73. 
Rai IN, Wiratmaja W, Semarajaya CGA \& Arsana D. 2009. Pengendalian getah kuning pada buah manggis dengan irigasi tetes, pemberian antitranspiran, dan pemupukan kalsium. Kerjasama Kemitraan antara Badan Penelitian dan Pengembangan Pertanian Kantor Pusat Jakarta dengan Universitas Udayana. Universitas Udayana, Denpasar.

Syah MJA, Mansyah E, Titin, Dewi, \& Usman F. 2007. Teknologi pengendalian getah kuning pada buah manggis. http://w.w.w.pustaka.deptan.go.id/ navasi/ kl1070102.pdf. Diakses pada 5 Agustus 2013.
Verheij EWM. 1992. Garcinia mangostana L. In: Verheij EWM \& Coronel RE. (Eds.). BuahBuahan yang Dapat Dimakan, pp. 77-181. Sumberdaya Nabati Asia Tenggara (PROSEA).

White TJ, Bruns TD, Lee S, \& Taylor J. 1990. Analysis of phylogenetic relationships by amplification and direct sequencing of ribosomal RNA genes. In: Innis MA, Gelfand DN, Sninsky JJ, \& White TJ (Eds.), PCR protocols: a guide to methods and applications. pp:315-322. Academic, New York. 